\title{
Yorùbá Sentential Negative Markers ${ }^{1}$
}

\author{
Taofeeq Adebayo \\ Tulane University
}

\begin{abstract}
The main claim of this paper is that Yoruba has only four sentential negative (SN) markers, kìi, kò, kó, and má, contrary to a traditional assumption that there are six of them (Fabunmi 2013). It is argued that these markers can be subcategorized into two morphemes: the $k$ morpheme and the má-morpheme. The $k$ - and má-morphemes are distinguished based on mood. The $k$-morpheme is used in realis mood while the má-morpheme is used in irrealis mood. Kì́, kò, and $k o ́$, which are taken to be allomorphs of the $k$-morpheme, are distinguished based on aspect and focus. It is shown that when the SN markers occur in a different modal-aspectual environment, this generally gives rise to two kinds of effect: (a) form-interpretation mismatches (Carlson 2006) or (b) the requirement for an additional morpheme.
\end{abstract}

Keywords: negative markers, allomorphs, form-interpretation mismatch, mood and aspect, Yorùbá

\section{Yorúbà sentential negative markers}

Carlson (2006) argues that functional items pose greater challenges to language acquisition than lexical items because they often exhibit mismatches (between form and interpretation) that are not found for lexical items. Given that most languages of the world have a relatively small number of morphemes that realize sentential negation (modern English for example has only 'not' and ' $n$ ' $t$ ' which according to R. Kayne (P.C.) have distinct syntactic distributions), Carlson's (2006) learner problem may arise for those trying to acquire languages where the negative markers number more than five and can sometimes give rise to mismatches. Shupamem, a Grassfields Bantu language, described in Nchare (2012), for instance, has up to nine distinct negative morphemes that are used to express sentential negation - which negative morpheme is used depends on tense, mood, and aspect. A similar phenomenon is found in Yoruba. Fabunmi (2013) suggests that Yoruba scholars like Bamgbose (1967, 1990), Ogunbowale (1970), Banjo (1974), Oke (1982); Awobuluyi (1978, 2016), and Adéwole (1999) recognize the forms in (1) as markers of negation in the language:

$\begin{array}{llllll}\text { a. } & \text { kò/ò } & \text { b. } & \text { kìi } & \text { c. } & \text { kó } \\ \text { d. } & \text { má/máà } & \text { e. } & \text { mó } & \text { f. } & \text { yé }\end{array}$

However, in what follows, I propose another way of looking at the members of (1). As will be shown shortly, I suggest that only (1a-d) can be regarded as true sentential negative (SN) markers in Standard Yoruba, and that (1e) is a Negative Polarity Item (NPI), while (1f) is a lexical verb. This

\footnotetext{
${ }^{1}$ I am very grateful to Richard Kayne and Anna Szabolcsi for their insightful comments and suggestions on the earliest version of this paper. I am thankful to Chris Collins whom I discussed some portion of the paper with. I am also grateful to Olanike Ola Orie for her suggestions on some earlier versions of the paper. As always, the remaining shortcomings are mine.
} 
move is motivated by independent factors described below and the fact that not all the scholars cited above take all of the forms in (1) to be negative markers in the language.

First, note that the distinction between kò and ò in (1a) and má and máà in (1d) is simply phonological, meaning that elements in each of the pairs are the same but surface with different phonological realizations conditioned by sociolinguistic variation. The list in (1) is largely based on Banjo (1974) who takes the forms in (1a\& b) as sentence negators, the one in (1c) as NP negator, while taking those in (1d) and (1f) as imperative negators. This list is mainly reproduced in Adewole (1999). Other Yoruba scholars do not include (1e\&f) in their discussion of negation in Yoruba. See Bamgbose (1967:20), Ogunbowale (1970:52), Oke (1982:248-9), Taiwo (2006:63) and Awobuluyi (2016:117-20), for example.

Consider now the following argument. The morpheme má/máà in (1d) can have the morpheme mó as a variant in Ọyọ́-İbàdàn Yoruba dialect (Fabunmi 2013:7). This does not make it a separate negative morpheme, however, just as the difference between $k \grave{o}$ and $\grave{o}$ in (1a) does not give rise to two separate morphemes. This variation is simply sociolinguistically conditioned. But in standard Yoruba, má and mó are two distinct morphemes, which both carry the NEG feature. The difference between the two is that má is a negative marker while mó is an NPI, a strong NPI for that matter. See a detailed description of mó in Adéwole (1990). Banjo (1974) himself, does not include (1d) as a negative marker but describes it as post-verbal negative adverbial (what we have described here as an NPI). Consider the following sentences:
a. Mọ́/má sùn mọ́
NEG sleep anymore
'Don’t sleep anymore.' (Ọ̀ộ-İ̀àdàn Yoruba dialect)
b. Má sùn mọ́
NEG sleep anymore
'Don't sleep anymore.' (Standard Yoruba)

In (2a), it can be seen that the SN marker má has a variant which resembles the NPI mó, while in (2b) the SN marker má is clearly distinct from the NPI mó. The consequent intuition, therefore, is that in Standard Yoruba, $m o ́$, which can be a phonological variant of the imperative negative marker $m a ́$ in some dialects of Yoruba, is not a negative marker but an NPI. To be sure, the meanings given to mọ in A Dictionary of the Yoruba Language (2008) include only 'again', 'anymore', and 'any longer'. Banjo (1974) and Adewole (1990) also gloss mó as 'anymore' and 'again' respectively in their examples, suggesting that the intuition developed here is on the right track. A diagnostic that can be used to test this intuition further is the parametric fact that Yoruba is not a negative concord language like French, which can have two negative markers within the same simple indicative clause. The glossing in (3a) violates this parameter for Yoruba, and so given the meaning that we get from the expression in (3a), mó can only be an NPI meaning 'anymore'. This fact is presented in (3b).
(3)
a. Adé
kò
sọ̀rọ
mọ́
Adé NEG say_word
'Adé is not talking/does not talk anymore.'
$\begin{array}{lllll}\text { b. } & \text { Adé } & \text { kò } & \text { sọ̀rọ́ } & \text { mọ́ } \\ & \text { Adé } & \text { NEG } & \text { say_word } & \text { anymore }\end{array}$
'Adé is not talking anymore.' 
The morpheme in (1f) also seems to be misplaced as it cannot be taken to be an SN marker. According to A Dictionary of the Yoruba Language (2008), yé means 'stop' or 'cease'. In fact, Awobuluyi (1967:21) glosses yé as 'stop'. For this reason, the structure in (4a) taken from Adewole (1999:398) cannot be said to have been properly glossed. In (4b), I give an alternative gloss that supports the view in this paper. To be sure, the negative-concord diagnostic in (3) is used for yé in (5), and it is clear from (5a\&b) that yé is far from being an SN marker.

(4)

$$
\begin{aligned}
& \text { a. Yé lọ } \\
& \text { *NEG go } \\
& \text { * 'Don't go.' }
\end{aligned}
$$

$\begin{array}{lll}\text { b. } & \text { Yé } & \text { lọ } \\ & \text { Stop } & \text { go } \\ & \text { 'Stop going.' } & \end{array}$

sọ̀rò Adé NEG *NEG say.word 'Ade did not stop talking.'

$\begin{array}{llll}\text { b. Adé } & \text { kò } & \text { yé } & \text { sọ̀rọ̀ } \\ \text { Adé } & \text { NEG stop } & \text { say.word } \\ \text { 'Ade did not stop talking.' } & \end{array}$

As demonstrated above, the morpheme yé is not an SN marker but a lexical verb meaning 'stop' or "cease" ${ }^{2}$. However, the fact that this morpheme has been taken for a negative marker raises an important question about how the semantic and syntactic treatment of SN markers differs from that of constituents like stop, disagree, etc., which tend to reverse the truth-value of a proposition in ways resembling the SN makers. I do not pursue this here. At any rate, the morpheme yé is not an SN marker. Based on the foregoing, a refined version of (1) is proposed in (6).

$$
\begin{aligned}
& \text { SN markers in Standard Yoruba } \\
& \begin{array}{lll}
\text { a. kò } & \text { b. kìí } \\
\text { c. kọ́ } & \text { d. } & \text { má }
\end{array}
\end{aligned}
$$

Further independent diagnostics can be invoked in support of (6) and against (1e\&f). In the syntactic literature, a widely used test of sentential negation is the Klima test originally proposed

${ }^{2}$ Ola Orie (P.C.) notes that yé is different from canonical lexical verbs in the language, in some sense. This is generally correct, given the fact that, unlike most verbs, yé cannot be used as the sole lexical verb in a simple clause. It always requires another verb. Consider the following:
a. Sọ ọ̀rọ
say word
b. Má sọ
ọ̀ọ̀
c. Yé sọ
NEG say
word
Stop say
ọ̀ọ̀
'Stop speaking'
word
d. *Ye
Stop
ọ̀rọ
word
'Speak' 'Don't speak'

(1d) is ungrammatical because there is no lexical verb that yé can apply to. Consider again the argument up to this point. $M a ́$ in (1b) yields a perfect negative interpretation of (1a) without adding any essential presupposition. Yé in (1c), on the other hand, does not yield this undiluted interpretation. In effect, yé presupposes that the action or event denoted by the verb to which it applies (for example, so 'say' in (1a)) is already ongoing. This characteristics of requiring an additional lexical verb in a clause, however, is not peculiar to yé. One might also make reference to the case of $f i$ 'use' which also has this property:
$\begin{array}{llll}\text { a. Mo } & \text { fi } & \text { síbí } & \text { jẹ } \\ 1 \mathrm{SG} & \text { use } & \text { spoon } & \text { eat }\end{array}$
èwà
b. *Mo
fi
síbí
'I used spoon to eat beans.'
1SG use spoon

Similar to the case of $y e ́$ in (1d), (2b) is ungrammatical because the clause does not have another lexical verb to which $f i$ can apply. The consequent intuition, then, is that there is a class of lexical verbs which cannot occur alone in a clause but must be used with other lexical verbs in a version tantamount to what has been described in the literature as verb serialization. Yé and $f i$ can be said to belong to this category of verbs. 
for English by Klima (1964). According to Klima (1964) and Jackendoff (1969), a sentence is negative if it can take a positive confirmation tag (as in 'He did not do it. Did he?), if it can be followed by negative appositive tags (as in 'The writer will not accept any suggestions, not even reasonable ones') or if it can occur in negative conjoined sentences ending with 'and neither did $\mathrm{X}$ ' (as in 'John did not show up yesterday, and neither did Paul'). However, this diagnostic cannot be used to test if the SN markers in (6) are indeed markers of sentential negation and if (1e\&f) are not because the correlates of these three syntactic structures are not directly available in Yoruba. A diagnostic that can be used, which is based on the Klima test, is the one proposed by Jackendoff (1969).

Jackendoff (1969:218) proposes that a sentence $\left[{ }_{s} \mathrm{X}-\mathrm{neg}-\mathrm{Y}\right]_{\mathrm{S}}$ is an instance of sentence negation if there exists a paraphrase 'It is not so that $\left[{ }_{s} \mathrm{X}-\mathrm{Y}\right]$ '. Given this diagnostic, it can be shown, for example, that kò (6a) in a sentence like Adé kò sộọ lánă (Ade NEG say.word in.yesterday, 'Ade did not talk yesterday') is indeed a marker of sentential negation by giving a paraphrase of the sentence as 'It is not so that [Adé sộộ lánă]' yielding 'It is not so that [Adé talked yesterday]'. The same thing can be done for kì in a sentence like Adé kì sọrọ̀ ní gbogbo igba (Ade NEG say.word in every.time, 'Ade does not talk every time'). The paraphrase 'It is not so that [Adé (maa-n) sọrọ̀ ní gbogbo igba]' can be given to yield 'It is not so that [Adé talks every time].' Kọ́ (6c) follows the same generalization. A sentence like Adé kọ ló wá (Adé NEG FOC.3SG come, 'it is not Ade that came') can be paraphrased as 'It is not so that [Adé ló wá]' to yield 'It is not so that [it is Adé that came].' This diagnostic, however, does not work for (6d) and (1e\&f) without further modification.

The reason is that $(6 \mathrm{a}-\mathrm{c})$ are markers of sentential negation in indicative clauses while $(6 \mathrm{~d})$ and of course (1e\&f) are not. Since (6d) and (1e\&f) are taken to be markers of sentential negation in imperative clauses in Fabunmi (2013), we can formulate an imperative version of Jackendoff's (1969) paraphrase test as follows: an imperative sentence $[x$-neg-Y] is an instance of sentence negation if there exists a paraphrase 'It is not so that $\mathrm{x}$ let it be the case that $[\mathrm{x}-\mathrm{Y}]$ ' (where $\mathrm{x}$ is existentially closed by an addressee, and $\mathrm{Y}$ is a given predicate). Using this revised test, it can be shown that (6d) in a sentence like Má lọ (NEG go, 'don’t go') is indeed a marker of sentential negation by giving the paraphrase of the sentence as 'It is not so that $\mathrm{x}$ let it be the case that $[\mathrm{x}-l o]$ ' yielding 'It is not so that $\mathrm{x}$ let it be the case that [x-go].' The same thing cannot be said of yé (1f), however, since it fails this test. For example, a sentence like Yé pariwo (stop (*NEG) shout, 'stop shouting') cannot be paraphrased to yield 'It is not so that $\mathrm{x}$ let it be the case that [x-shout]'; rather, the meaning that is available is that $\mathrm{x}$ (the addressee) stop the act of shouting with the presupposition that this action of shouting is already ongoing. Such presupposition does not exist for má which is a true marker of sentential negation in imperative clauses. (1e) fails this test as well in that a sentence like Mọ́ lo (anymore go) which, though grammatical if glossed as [NEG go] to mean 'Don't go' in Òyọ́-İbàdàn Yoruba dialect (Fabunmi 2013:7), is not grammatical in Standard Yoruba since mó means 'anymore', and as result, the paraphrase 'It is not so that $\mathrm{x}$ let it be the case that $[\mathrm{x}-l o]$ ' is not available for this sentence in Standard Yoruba, even though it is available in Ộọ́-İbàdàn Yoruba dialect.

Having established that only four SN markers can be identified in Yoruba, I propose further that the four SN markers are simply two morphemes. This is the major concern of Section 2, where I argue that the four negative markers are simply two morphemes with one of them having three allomorphs. Section 3 explores the aspectual, modal, and focus distributions of the SN markers and discusses the two kinds of effects that arise when an SN marker appears in an environment in which it is not defaultly used. In Section 4, I examine the syntax of the negative markers, noting that they 
do not have a unified syntax as a result of their interaction with aspect, mood, and focus. Section 5 concludes with a summary of the paper.

\section{Kìi, $k \grave{o}$, and $k \grave{g}$ as allomorphs of the $k$-morpheme}

Given the intuition that primitive functional elements are often very minimal in natural language, it seems right to pursue the idea that kǐ́, kò, and $k o ́$ are allomorphs of the same NEG morpheme whose surface forms depend on aspect, focus, and phonological constraints. It should already have been noticed that the three SN markers look similar as the only difference among them is the vocalic elements. The allomorphy proposal for the $k$-morpheme goes as follows. In the Minimalist Program of Chomsky (1995, 2001), syntactic objects end up in their final positions in two ways: (i) through base generation (external merge) where the syntactic object, selected from the lexical array and merged with other constituents, remains in situ after this operation; and (ii) through internal merge where the syntactic object, selected from the lexical array and merged with other constituents, moves to a new position in the workspace. I propose that negation in the realis mood is characterized by an underspecification of the phonological content of the negative morpheme. This means that numeration (Chomsky 1995) involves only the $k$-morpheme so that its vocalic specification is determined at the syntax-phonology interface. If the $k$-morpheme is externally merged with a perfective aspect, it comes out as kò; if it is merged with an imperfective aspect, it comes out as kì́; and if it is merged with focus, it comes out as kọ.

However, the idea that there is a morpheme that is made up of only a consonant sound in Yoruba is counter-intuitive with respect to the general idea that Yoruba syllables are canonically $\mathrm{CV}$ or $\mathrm{V}$. However, the proposal here is that the $k$-morpheme underlyingly has a vocalic element whose ROOT is specified but whose place is unspecified so that it is the place value of the vocalic element (and not the whole segment) that is supplied at the phonology-syntax interface before SPELLOUT and when the syntactic operation of NEG raising takes place (see below). This is illustrated in (7).

\section{Underspecification of the $k$-morpheme}

\begin{tabular}{|c|c|c|c|c|}
\hline $\begin{array}{l}\text { Structure in } \\
\text { the lexicon }\end{array}$ & aspect/focus & $\begin{array}{c}\text { Syntax/Phonology } \\
\text { interface } \\
\text { (Place specification) }\end{array}$ & SPELLOUT & $\begin{array}{c}\text { Non-emphatic } \\
\text { environment }\end{array}$ \\
\hline a. $\mathrm{k}+\mathrm{V}_{\mathrm{ROOT}}$ & perfective & $\mathrm{k}+\mathrm{o}$ & kò & ò \\
\hline b. $\mathrm{k}+\mathrm{V}_{\text {ROOT }}$ & imperfective & k+ìí & kìi & ií \\
\hline c. $\mathrm{k}+\mathrm{V}_{\text {ROOT }}$ & focus & k+ó & kó & $x$ \\
\hline d. $\mathrm{k}+\mathrm{V}_{\text {ROOT }}$ & non-clausal & $\begin{array}{c}\mathrm{k}+\mathrm{i} / \mathrm{u} \text { (after redundancy } \\
\text { rule) }\end{array}$ & & \\
\hline
\end{tabular}

The conception in (7) is that in the underlying representation of the $k$-morpheme, a vowel is present, but its place value (i.e. \pm low, \pm back, etc.) is unspecified. It is at the syntax-phonology interface, however, that this specification is done. After SPELLOUT or after the syntactic operation of NEG raising has taken place, the $k$-morpheme can be dropped in rapid speech but not in emphatic environments. But $o ́$ is not possible since the allomorph $k o ́$ is always used in emphatic environments. This is what $\boldsymbol{X}$ in (7d) indicates. However, within the N-ki-N NPI (Koch 2005; e.g. ibi-ki-ibi 'anywhere'), discussed below, which is not a clausal position, this specification is not active. As a 
result, when the place feature of the $\mathrm{V}$ in the $k$-morpheme is to be specified because of consonant clustering which is forbidden in Yoruba, Pulleyblank's (2003) redundancy rule, which supplies the front and back high vowels /i/ and /u/ automatically in most phonological processes requiring vowel epenthesis, is assumed to be active, so that for bàbá-k-bàbá (father-NEG-father) 'any father', the resulting form after the redundancy rule has applied is bàbá-kí-bàbá. Of course, this is applicable to vowel-initial nouns as well. Take enikẹni in (13) for example; the full form is eni-ki-eni. But this case gives rise to vowel hiatus which is resolved by the deletion of $/ \mathrm{i} /$.

There is a useful syntactic operation that readily lends itself to an illustration of how the $k$ morpheme is internally merged. This is the syntax and semantics of NPIs offered in Collins and Postal (2014). Collins and Postal (2014), henceforth C\&P (2014), identify two types of NPIs that pattern with the traditional categories of NPIs: strict NPIs, which are licensed in antiveridical context and the non-strict NPIs which, in addition to being licensable in antiveridical contexts, can occur in veridical contexts (Giannakidou, 2011). In C\&P (2014), the former is regarded as Unary NEG NPI (Type 1), while the latter is taken to be Binary NEG NPI (Type 2). This categorization is different from the traditional categorization in essential theoretical terms. This is a detail I am not addressing here (see C\&P 2014:6 for a more elaborate discussion); it is sufficient here to establish a general understanding of these two types in the C\&P (2014) sense.

In C\&P (2014), NPIs are interpreted as consisting of NEG, a covert existential quantifier, and the NP that is quantified. A Type 1 NPI contains only one NEG and requires negation somewhere in the structure while a Type 2 NPI has two NEGs and does not require any negation in the structure. For instance, anybody in (8) is a Type 1 NPI which contains one NEG and requires the n't morpheme. In (9), anything, a Type 2 NPI, contains two NEGs and does not require any negative morpheme in the structure.

$$
\begin{aligned}
& \text { a. I didn't see anybody } \\
& \text { b. I did.NEG see [[<NEG }>\text { SOME] body }] \text { (Collins et al. 2017) }
\end{aligned}
$$
a. If you see anything, tell me.
b. If you see [[<NEG $>[<\mathrm{NEG}>\mathrm{SOME}]]$ thing], tell me
(Collins et al. 2017)

For the purpose of the present paper, I focus only on the Type 1 NPIs to account for the allomorphy status of three of the Yoruba SN markers. Based on the assumption that NPIs contain NEG, Collins et al. (2017) analyze structures containing NPIs in terms of Classical NEG-raising, a phenomenon in which NEG originates in the NPI (or in a subordinate clause-not relevant here) and raises to the post-auxiliary position (for English). I will return to the notion of Classical NEGraising shortly. First, I explore the cross-linguistic interpretation of Type 1 NPIs. Based on C\&P (2014) and Collins et al. (2017), I assume that (10) represents a cross-linguistic interpretation for Type 1 NPIs.

\section{[[NEG SOME] NP]}

Where NEG and SOME can be null or overt, and the order of the elements can vary crosslinguistically, so that (10) works fine for English. For Ewe the structure is [[SOME NP] NEG] (see a detailed description of Ewe NPIs in Collins et al., (2017)), while for Yoruba, we have [NP [NEG SOME]]. Consider (11a\&b).

$$
\begin{aligned}
& \text { a. I said nothing. } \\
& \text { b. I did not say anything. }
\end{aligned}
$$


In (11a), NEG is overtly spelt out as no and SOME is covert in the n-word nothing, while SOME is spelt out as any and NEG is null in anything in (11b). (11a) and (11b) can be given the same interpretation as in (12).

$$
\neg \exists \mathrm{x}[\operatorname{thing}(\mathrm{x}) \wedge \text { say }(\mathrm{I}, \mathrm{x})]
$$

The basic syntactic difference between the two is that in (11a) NEG does not raise to the post-AUX position while it does in (11b) in a manner consistent with what C\&P (2014) call Classical NEGraising. This is shown below.

$$
\begin{aligned}
& \text { a. I said }[[\mathrm{NEG}<\mathrm{SOME}>] \text { thing] } \\
& \text { b. I did } \mathrm{NEG}_{1} \text { say }\left[\left[<\mathrm{NEG}_{1}>\mathrm{SOME}\right]\right. \text { thing] }
\end{aligned}
$$

In the C\&P (2014) framework, <..> signifies that an element is silent. Based on the foregoing, Collins et al. (2017) arrive at two parameters that distinguish English NPIs from Ewe NPIs. The first parameter is that NEG does not leave a copy when it raises in English while it does in Ewe. The second one is that in structures containing NPIs, NEG optionally raises in English while it obligatorily raises in Ewe.

Turning now to Yoruba, there are NPIs in the language which pattern with the description of Type 1 NPIs above (however, I do not explore the details of Yoruba NPIs here). Consider the Yoruba N-ki-N form of NPI (Koch 2005) in (13). These are somewhat close to the English anyNPIs. As expected, they have only one NEG and require negation in the structure:

$$
\begin{array}{llll}
\text { Adé } \quad \text { kò } & \text { rí } & \text { ẹnikẹ́ni } \\
\text { Adé } \quad \text { NEG } & \text { see } & \text { anybody } \\
\text { 'Adé did not see } & \text { anybody.' } &
\end{array}
$$

Applying (10), we have:

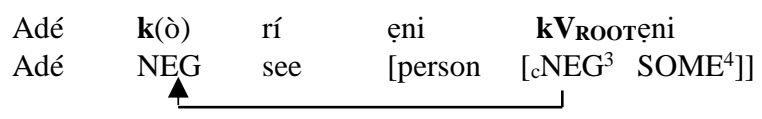

In (14), NEG originates in the NPI and obligatorily raises to the preverbal position leaving a copy. In the framework of Collins et al. (2017), there is room for ${ }_{c} \mathrm{NEG}$ to be phonologically identical to the raised NEG. My assumption is that this is an instance where this is the case. The main difference between $k \boldsymbol{V}_{\text {Rоoт }}$ (cNEG) and $k \grave{o}$ (raised NEG) can be explained. When $k$ raises to preverbal position, it occupies a position in the syntax where it has to stand alone. Since Yoruba as a language does not allow a consonant to stand in isolation without a vowel, $k$ has to surface with a vowel, to satisfy the syllable well-formedness constraint (Ola, 1995), which forbids a non-moraic consonant, such as /k/, from standing alone as a syllable. The vocalic derivation for $k$ is determined by the aspectual modal environment where $k$ is raising to. Contrast (15) where $\mathrm{k}$ raises to an imperfective indicative environment, with (14) where $k$ raises to a perfective indicative environment.

$$
\begin{array}{lllll}
\text { a. Adé } & \text { kìi } \quad \text { jẹ } & \text { ohunkóhun } & \text { lálẹ́ } \\
\text { Adé } & \text { NEG eat anything } & \text { at.night } \\
\text { 'Adé doesn't eat anything at night (habitually).' } &
\end{array}
$$

${ }^{3}$ cNEG= copy NEG

${ }^{4}$ The second NP eni is interpreted as SOME here pre-theoretically. 
$\begin{array}{lllllll}\text { b. Adé } & \mathbf{k}(\mathbf{i i ́}) & \text { jẹ } & \text { ohun } & \mathbf{k V} \text { ROOT } & \text { óhun } & \text { lálé } \\ \text { Adé } & \text { NEG } & \text { eat } & \text { [thing } & \text { [cNEG } & \text { SOME] } & \text { at.night }\end{array}$

Note, however, that the case of kó is different as shown in (16). The $k$-morpheme in the NPI cannot raise to a position where it can negate the focus phrase. There are two instances of negation here: one originates from within the NPI and is internally merged in a post-AUX position in the embedded clause; the other is externally merged and is pronounced in the Matrix clause. What is interesting here, however, is that we are able to see how the syntactic operation of NEG raising helps illustrate how the $k$-morpheme is derived (as in (14) and (15)) and how this derivation is done in cases not involving NPI. The derivation of $k o ́$ in (16) is done at the syntax-phonology interface. This has been captured in the diagram in (7). In other words, $k o ́$ enters the derivation via numeration (Chomsky 1995:225) while kò raises from within the NPI.

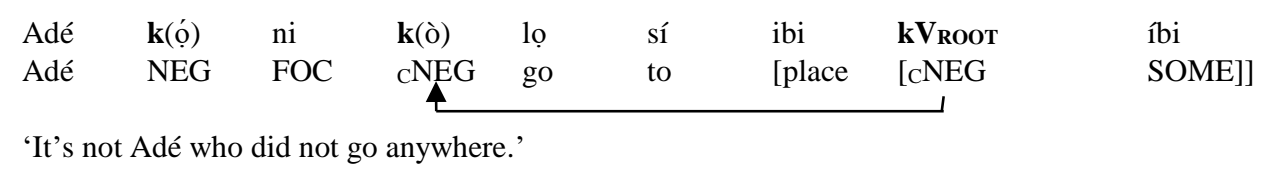

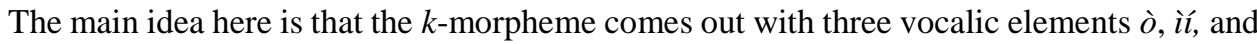
$o ́$ depending on aspect and focus, whether or not it enters the derivation via numeration or NEG raising. It comes out with $o$ in non-progressive aspect, $i \iota ́$ in progressive aspect, and $o ́$ in focus constructions. However, there are cases where these vocalic elements, with the exception of $\dot{o}$, are used without the $k$-morpheme (refer back to (7)). While these cases are mainly phonological, as A. Szabolcsi (P.C.) rightly suggests ${ }^{5}$, it seems that there is room for some distinctions based on syntactic distributions: the $k$-morpheme is used in wider syntactic environments than the vocalic elements. It is proposed here that these vocalic elements assimilate the NEG feature of the $k$ morpheme and can, therefore, exist without the $k$-morpheme in some contexts, but not where the $k$ morpheme is involved in some form of emphasis or focus in a simple indicative clause ${ }^{6}$.
$\begin{array}{llll}\text { a. Adé } & \text { KÒ } & \text { jẹ } & \text { ìrẹsì } \\ \text { Adé } & \text { NEG } & \text { eat } & \text { rice }\end{array}$
Adé
b. Adé ò jẹ ìrẹsì
Adé assNEG eat rice
'Ade did not eat rice.'

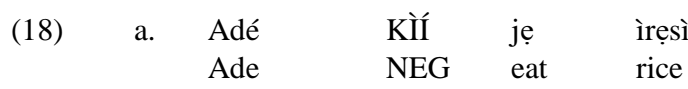

'Ade does NOT eat rice (habitually).'

\footnotetext{
${ }^{5}$ Deleting a consonant from a functional element in rapid speech is well attested in the Yoruba grammar. An example is the case of the future marker 'yoo' in which ' $y$ ' gets deleted as in Won (y)óo lo 'They will go'.

${ }^{6}$ Note that the account I have provided here is purely novel and completely improvised. Syntactic feature assimilation is not a registered concept. I have only used it here as a heuristic to account for why the focus SN marker $k o ̣$ does not reduce to $o$ like the other $k$-allomorphs.
} 


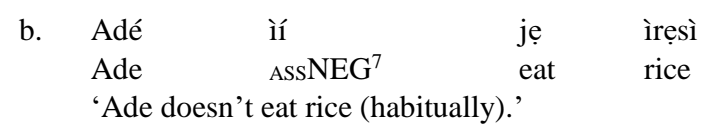

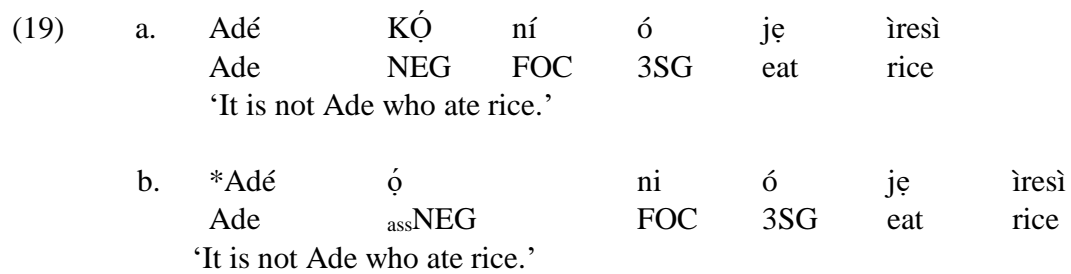

In the examples above, ass NEG is used heuristically to indicate that the vocalic morphemes are assimilation NEGs and are not themselves NEGs. In other words, they carry assimilation NEG features. The idea here is that the vocalic morphemes manifest the NEG feature but are not themselves the carrier of the NEG feature. This treatment of the vocalic elements is closely related to the assumption in Zeijlstra (2014) that if a morpho-syntactic element X manifests the presence of some semantic feature $\mathrm{F}$, but $\mathrm{X}$ cannot be assumed to be the carrier of $\mathrm{F}$, then $\mathrm{X}$ is an uninterpretable feature. Following the same line of thinking, let us improvise syntactic feature assimilation as follows: if a phonological process reduces a morpho-syntactic element $\mathrm{XY}$, carrying feature $\mathrm{F}$, to $\mathrm{Y}$ and $\mathrm{Y}$ manifests the presence of $\mathrm{F}$, but there is a syntactic distinction between $\mathrm{XY}$ and $\mathrm{Y}$, then $\mathrm{Y}$ carries an assimilation $\mathrm{F}$ and not $\mathrm{F}$ itself. ass $\mathrm{F}$ (assimilation $\mathrm{F}$ ), therefore, is a place holder for $\mathrm{F}$, whose syntactic distribution is more limited than that of F. In (17) and (18), note that the ass NEG can stand in place of NEG when there is no contrast involved. But when NEG is contrasted, the assNEG cannot stand in its place. Since $k o ́$ is always in contrast and there is no context in which it is non-contrastive, the ass NEG * $o$ is not possible in any context. This explains why (19b) is ungrammatical. To be sure about this, the case of kil should be mentioned. Kilı can also be used to negate a focus phrase (details of this can be found in the next section). When this happens, the ass NEG il cannot be used as shown below. This is particularly when the clause is a simple indicative clause.

\begin{tabular}{|c|c|c|c|c|c|c|}
\hline \multirow[t]{2}{*}{ a. } & $\begin{array}{l}\text { Kií } \\
\text { NEG }\end{array}$ & $\begin{array}{l}\mathrm{se} \\
\mathrm{COP}\end{array}$ & $\begin{array}{l}\text { Adé } \\
\text { Ade }\end{array}$ & $\begin{array}{l}\text { ni } \\
\text { FOC }\end{array}$ & $\begin{array}{l}\text { ó } \\
\text { 3SG }\end{array}$ & $\begin{array}{l}\text { jẹ } \\
\text { eat }\end{array}$ \\
\hline & 'It is $n$ & who at & & & & \\
\hline \multirow[t]{2}{*}{ b. } & *ìí & se & Adé & ni & ó & jẹ \\
\hline & NEG & COP & Ade & FOC & $3 \mathrm{SG}$ & eat \\
\hline
\end{tabular}

The essential claim here is that the NEG raising in (14), (15), and (16) and the idea pursued in (17) through (20) are evidence that kì́, kò, and kó are variants of the same $k$-morpheme which is also found in N-ki-N NPIs. The variation in vowel is only due to the syntactic environments in which it is used and the phonological well-formedness constraint in Yoruba which forbids a syllable made up of only a non-moraic consonant like $/ \mathrm{k} /$.

However, there is a problem that arises from using the C\&P (2014) framework. Note that in the NPIs above, there is some sort of reduplication: eni in enikeni, ibi in ibikibi, and ohun in ohunkohun. So far, the reduplicated copies and their base forms appear to be having different interpretations. This cannot be right as it violates Kayne's (2016) no homophony principle.

7 ass NEG= assimilation NEG 
Therefore, while it is clear that eni comes out as person, ibi as place, and ohun as thing, it is not immediately clear what the contribution of their reduplicated counterparts would be, but it could well be posited that the copies in front of $k$ are reduplications whose underlying semantics spells out as SOME. This might be in the right direction given that reduplications of this sort abound in Yoruba that could be given similar treatment.

Granted that kì́, $k \grave{o}$, and $k o ́$ are allomorphs of the $k \mathrm{~V}_{\text {ROOT }}$ morpheme, it follows that Yoruba has only two morphemes for the expression of sentential negation: the $k \mathrm{~V}_{\mathrm{ROOT}}$ morpheme and the $m a ́$-morpheme which are distinguished based on mood. This is captured in the following table.

Table 1. Aspectual-modal distribution of Yoruba NEG morphemes

\begin{tabular}{|c|c|c|c|}
\hline Aspect/ & & \multicolumn{2}{|c|}{ Mood } \\
\hline & Types & Realis $\left(k \mathrm{~V}_{\mathrm{ROOT}}\right)$ & Irrealis (má) \\
\hline Perfective & & $k \grave{o}$ & \multirow{5}{*}{ má } \\
\hline \multirow{3}{*}{ Imperfective } & Event-in-progress & kò & \\
\hline & Continuous & kò & \\
\hline & Characterizing (habitual) & kìi & \\
\hline Focus & & $k o ́$ & \\
\hline
\end{tabular}

Table 1 not only displays modal distinction; it also displays aspectual and focus distinctions among the allomorphs of the $k \mathrm{~V}_{\text {ROот }}$ morpheme. We see in the table that the $k \mathrm{~V}_{\text {RоOт }}$ morpheme comes out as $k o ́$ in the context of focus. It comes out as $k \grave{o}$ in the perfective aspect. The imperfective aspect, however, is a bit complex. Deon (2009) divides the imperfective aspect into three subgroups: (i) Event-in-progress (progressive) as in 'Ade is reading in his room'; (ii) Continuous as in 'Ade lives in Texas'; and (iii) Characterizing (habitual) as in 'Ade goes to bed after dinner'. The $\mathrm{kV}_{\text {ROOT }}$ morpheme surfaces as kò in both event-in-progress and continuous, while it comes out as kì in characterizing (habitual).

What Table 1 displays, however, is an unmarked (default) distribution; it will be clear from the next section that the SN markers can be used in different aspectual-modal environments in a way that usually gives rise to mismatches and the requirement for the presence of an additional morpheme. What can be taken from the foregoing is that, upon closer inspection, functional (or morphemes exhibiting primitive functional) elements are very few in number so that the multiplicity of negative markers described in Nchare (2012), for example, might be amenable to a systematic reduction that generates a minimal set of the functional elements. This kind of systematic reduction is the main purpose of Kayne (2016), where the different types of English there are reduced to one through the no-homophony hypothesis. In what follows, I present data that demonstrate how the negative markers are used with respect to aspect, mood, and focus.

\section{Focus and aspectual-modal distributions of SN markers in Yoruba}

If we assume that kò and kì are the SN markers for past and present realis mood, disregarding aspect, and that má negates the irrealis mood, while kọ negate focus irrespective of the nature of what aspect is involved, we might be tempted to think that the jobs of these negative markers are clearly spelt out for each of them so that the idea put forward in the previous section appears to be neatly worked out. But as the data presented below will suggest, this is far from being so. However, before going 
to this detail, the appropriate point of departure seems to be a review of the relationship that negation has with tense, mood, and aspect in Yoruba.

Tense is not overtly marked in Yoruba, though the temporal frame of the verb can be expressed optionally by temporal adverbials (Fabunmi 2013), and there is a prospective aspectual morpheme yoo/a, which some writers have claimed is the future tense marker (see Hewson 2010). By implication, the same structure is used to express the present tense and the past tense, with the distinguishing factor being the context or the optional modification of a temporal adverbial. Aspect and modality on the other hand are overtly marked in the syntax and this has consequences for the choice of SN markers. With this background, we can now explore how modal, focus, and aspectual sentences are negated by the SN markers in what follows.

3.1 Negation in indicative simple present and past. (21) shows that only kò can be used effectively in indicative present and past. The other three SN markers either yield wrong interpretation or are ungrammatical. Note also that it is only kò that is used in indicative present and past progressive and even in present and past evidential. What is interesting about its use in the progressive is that it deletes the progressive marker, as seen in (22).

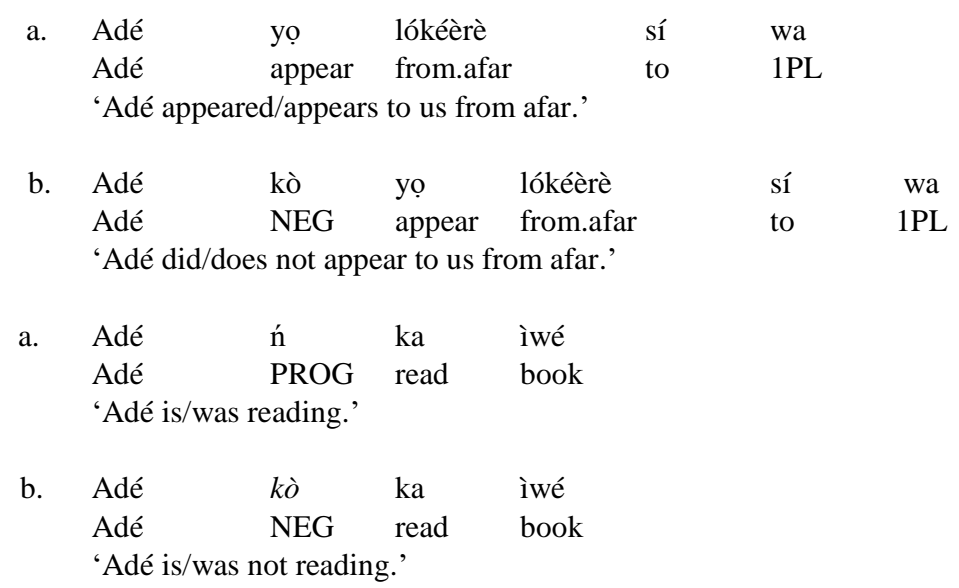

This fact generally supports the argument that kò is used unmarkedly in realis mood. Indicative mood, simple or past, is a realis mood, and the fact that only kò is possible in this context suggests that the argument in Section 2 is in the right direction.

\subsection{Negation in simple future, perfective future, and imperfective future (prospective).}

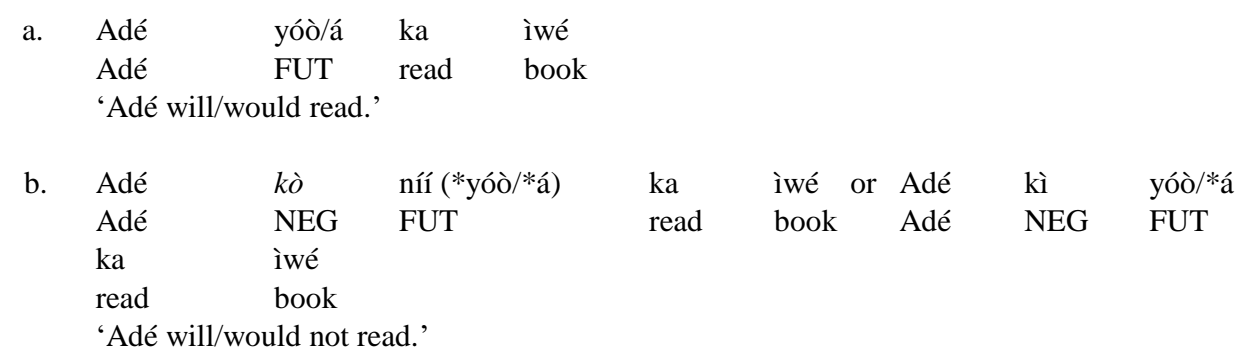


Again, only kò works fine in prospective negation. But it has some inconsistencies: note that kò cannot occur with the prospective morpheme yóo without bringing some changes in the morphology of the prospective marker. If $k \grave{o}$ is to be used, níl has to be the one signaling the prospective mood. If yóò is to be retained, kò has to change to kì, a form whose existence in this context can only be explained phonologically: it could be suggested that what we see here is an instance of dissimilation where two adjacent functional elements are forbidden from sharing the same place value for their vocalic elements: yóò and kò share the same place value for their vocalic elements, so dissimilation occurs raising the place specification for the /ò/ in kò to the default /ì/. The á form of yoo does not surface at all in negation. This is the case in the prospective perfective and imperfective presented in (24) and (25) respectively.

$\begin{array}{llcc}\text { a. Adé } & \text { yóò } & \text { ti } & \text { sùn } \\ \text { Adé } & \text { FUT } & \text { PFV } & \text { sleep } \\ \text { 'Adé will/would have slept.' } & \end{array}$

$\begin{array}{llllllll}\text { b. Adé } & k o ̀ & \text { níí(*yóò/*á) } & \text { tîn } & \text { sùn or } & \text { Adé } & \text { kí } & \text { yóò/*á } \\ \text { Adé } & \text { NEG } & \text { will } & \text { PFV } & \text { sleep } & \text { Adé } & \text { NEG } & \text { FUT } \\ \text { tî̀ } & \text { sùn } & & & & & \\ \text { PFV } & \text { sleep } & & & & & \\ \text { 'Adé will/would not have slept.' } & & & & & \end{array}$

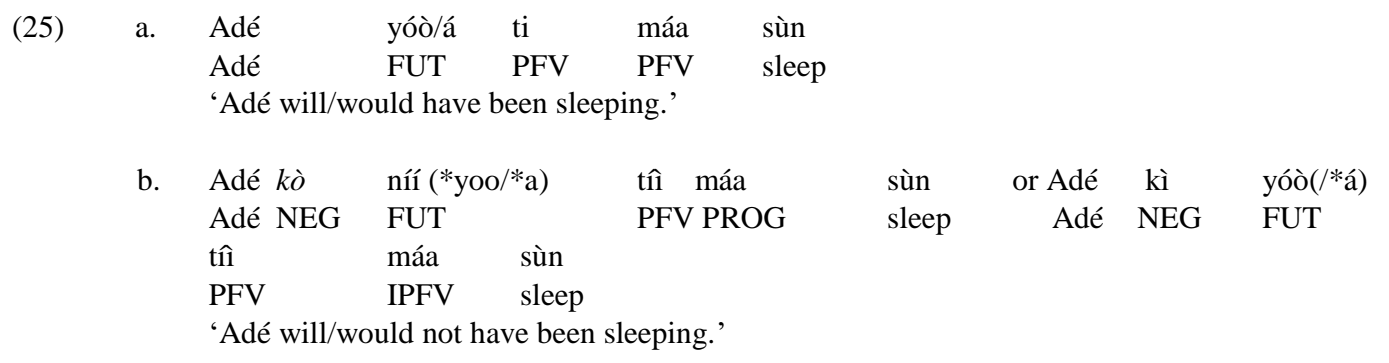

The data above suggest that the distribution of kò is far much wider in the perfectiveimperfective domain than kî́. The result of this is that in addition to being the negative marker in all realis perfective aspects, $k o ̀$ is used in present, past, and future progressive in line with the representation in Table 1.

3.3 Negation in indicative present and past habitual. As shown in (26), kì and kò can be used in present and past habitual, but since kil can negate the habitual sentence without any overt progressive or imperfective marker present, and kò cannot do this without the progressive $n$, the correct intuition seems to be that kì is the unmarked habitual SN marker. But since we have seen above that it does not surface in progressives, we can assume that kil is the unmarked negative marker only in present and past habitual. This too is in line with Table 1.
a. Túndé máa-ń jẹ ẹ̀wà l'ójoojúmọ̀
'Túndé eats/used to eat beans everyday.'
Túndé IPFV eat beans in.everyday
b. Túndé kî́ jẹ ẹ̀wà l’ójoojúmọ́
Túndé NEG eat beans in.everyday
'Túndé does/ did not use to eat beans everyday.'




\begin{tabular}{|c|c|c|c|c|c|}
\hline $\begin{array}{l}\text { Túndé } \\
\text { Túndé }\end{array}$ & $\begin{array}{l}k \grave{o} \\
\text { NEG }\end{array}$ & $\begin{array}{l}\text { ń } \\
\text { PROG }\end{array}$ & $\begin{array}{l}\text { jẹ } \\
\text { eat }\end{array}$ & $\begin{array}{l}\text { è̀wà } \\
\text { ẹ̀wà }\end{array}$ & $\begin{array}{l}\text { l'ójoojúmọ́ } \\
\text { in.everyday }\end{array}$ \\
\hline
\end{tabular}

3.4 Negation in present and past copula. While kì and kò are both possible in copula constructions as shown in (27), it turns out that kil is not possible when the complement is an adjective. This can be seen in (28ci) and (28cii). We can also observe that when the SN markers kò and kì are preceded by a third-person singular pronoun, such pronoun gets deleted so that the subject argument in the syntax is absent while it is present in the semantics; this then is a case of form-interpretation mismatch. Since this is a realis mood, it makes sense that only kò and kì are possible.
a. i. Túndé jẹ́ akẹ́kọ̀ọ́ ni UI Túndé COP student at UI 'Túndé is a student at UI.'
b. i. Túndé kò jẹ́ akẹ́kọọ ní UI Túndé NEG COP student at UI 'Túndé is not a student at UI.'
c. i. Túndé kìi se akẹ́kọọ ni UI Túndé NEG COP student at UI
'Túndé is not a student at UI.'
ii. $\mathrm{O}$ jẹ́ akẹkọ ni UI 3SG COP student at UI 'S/he is a student at UI.'
ii. $K o ̀ \quad$ jẹ́ akẹoọọ ní UI NEG COP student at UI 'S/he is not a student at UI.'

ii. Kì se akẹ́kọọ ni
NEG COP student at
'S/he is not a student at UI.'
a. i. Túndé ga
Túndé be.tall
ii. Ó ga 3SG be.tall
'S/he is tall.'
b. i. Túndé kò ga
Túndé NEG be.tall
'Túndé is not tall'
c. i. *Túndé kì $\quad$ ga
Tunde NEG be.tall
'Tunde is not habitually tall.'
ii. $K \grave{g} \quad \mathrm{ga}$
NEG be.tall
'S/he is not tall'
ii. *Kĭ ga
NEG be.tall
'He is not habitually tall.'

3.5 Negation in prohibitive, imperative, interrogative, subjunctive, and potential. Kò and má are used in prohibitives and imperatives respectively as can be seen in (29) and (30).

$$
\begin{array}{llll}
\text { E } & \text { kò } & \text { gbọdọ } & \text { wọlé } \\
\text { 2PL } & \text { NEG } & \text { must } & \text { enter } \\
\text { 'You must not enter.' } &
\end{array}
$$

$\begin{array}{lll}\text { E } & \text { má } & \text { wọlé } \\ \text { 2PL NEG } & \text { enter } \\ \text { 'Don't } & \text { enter.' }\end{array}$

However, note that the imperative in (30) can pass for both negative imperative and prohibitive. Kò cannot be used in the prohibitive mood without the modal gbodọ, and it is not possible at all in negative imperative. Má is okay in both, suggesting that it is the unmarked element in this context, while kò is marked. All of the SN markers are possible in interrogatives as most of the structures we have seen for each of them so far can easily be turned into questions. In potential, only má is possible with some variations. Consider (31) and (32). 


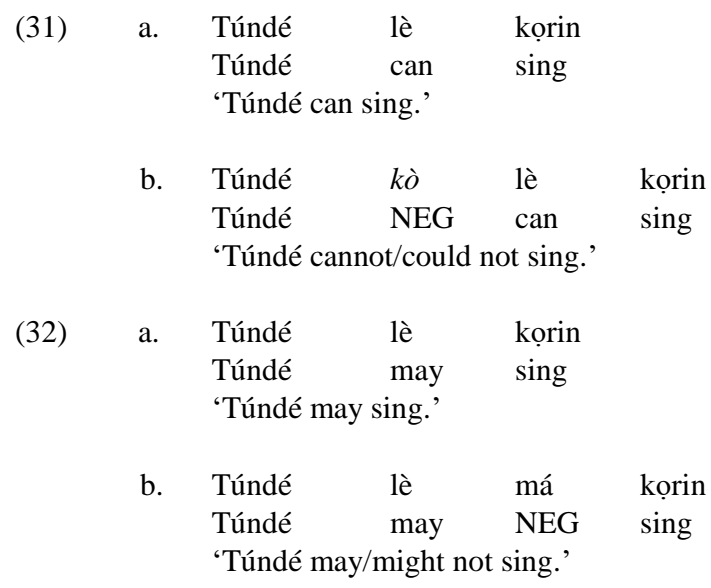

When lè, the potential morpheme, signals ability, to negate it, the SN marker kò has to be used and precede it, but when it signals possibility, the SN marker má has to be used and follow it. This fact favors the distinction we have made between the $k$-morpheme and the má-morpheme. An expression of ability is a realis mood whereas an expression of possibility is an irrealis mood. But there is an important question here: in Yoruba, SN markers are generally preverbal; why is má post-modal in (32b)? This effect has already been noted in De Haan (1997) who observes that the interaction of negation and modality is such that it can be reflected in the scope interaction between markers of negation and modality. As De Haan (1997:104) observes, in (31b) negation has scope over the modal (NEG (MOD (p))) while in (32b), negation has scope under the modal (MOD (NEG (p))). It can be suggested that this scopal distinction arises simply to resolve an ambiguity embedded in the modal lè so that it has scope over negation in its irrealis sense while it has scope under negation in its realis sense.

The subjunctive mood, on the other hand, seems to come with a load of surprises. First, only kĭı, kò, and má are possible in subjunctive mood. This is illustrated in (33).
a. Tí kìi bá se ìwọ ni
If NEG were COP 2SG FOC
'If it had not been you...'
b. Tí Pọọ̣lù kò bá jẹ àpú yẹn ni...
If Paul NEG were eat apple that FOC
'If Paul had not eaten that apple...'
c. Mo dábàá pé kí Pọ̣ọ̀lù má jẹ ápù
1SG suggest that such.that Paul NEG eat apple
'I suggest that Paul does (should) not eat an apple.'

What we see here is that the use of both kì and kò requires the presence of a subjunctive marker, bá. What can be inferred from this is that since kì and kò are merged in an irrealis position, a marked position for them, they require the presence of a marker that explicitly indicates the irrealis modality of the phrase they are merging with. Since má is in an unmarked position (irrealis mood), such requirement is redundant.

Second, the subjunctive mood allows kò and má to be used in the same clause. Take a look at the following sentences. 

a. Adé
$\begin{array}{lll}\text { kò } & \text { báà } & \text { má } \\ \mathrm{NEG}_{2} & \text { even.if } & \mathrm{NEG}_{1}\end{array}$
ríi, wàhálà yín
problem
nìyẹn Adé $\quad \mathrm{NEG}_{2}$ even.if $\mathrm{NEG}_{1}$ see.3SG
b. E kò báà má lọ, 2PL $\mathrm{NEG}_{2}$ even.if $\mathrm{NEG}_{1}$ go 'Even if you do not go, that is your problem.'
wàhálà yín problem your
FOC.that
nìyen
FOC.that

The examples in (34) will appear to contradict the result of the negative concord test in (3) and (5), but this is not the case. First, the sentences in (34) are not simple indicative clauses. Second, and most importantly, this is a case of form-interpretation mismatch (Carlson, 2006): a form is present in the syntax but has no semantic effect. Kò is used in subjunctive clauses but does not contribute to their meaning. In the sentences in (34), If $\mathrm{NEG}_{1}$ is removed, the sentences are perfectly fine. The only difference is that the subjunctive clauses are no longer negative, even with the presence of $\mathrm{NEG}_{2}$. This is shown in (35). However, if $\mathrm{NEG}_{2}$ is removed in both (34) and (35), the sentences are ungrammatical. Consequently, it does not matter whether the subjunctive clause is negative (34a\&b) or positive (35a\&b), kò does not contribute any meaning to the semantics.
a. Adé
$\mathrm{NEG}_{2}$ even.if
kò báà
Adé
rii, wàhálà yin
nìyẹn
'Even if Adé sees it, that is your problem.'
b. $\quad$ E
2PL
$\begin{array}{lll}\text { kò } & \text { báà } & \text { lọ, } \\ \mathrm{NEG}_{2} & \text { even.if } & \text { go }\end{array}$
'Even if you go, that is your problem.'
FOC.that

What the use of kò in $(35 \mathrm{a} \& \mathrm{~b})$ suggests is that kò is semantically redundant in this subjunctive context. It is, therefore, an element present in the syntax but with no import in the semantics. This redundancy or mismatch can be explained away by the fact that it is in a marked position. This phenomenon of having a negative marker without semantic interpretation is not uncommon in natural language; in fact, this is the phenomenon described in the literature as expletive negation (C\&P 2014: 228). Pullum and Huddleston (2002: 845-846) describe a number of expletive negation cases from English, and C\&P (2014:228) note that this is quite productive in other languages.

3.6 Negation in focus constructions. Yoruba has a distinct focus construction which can be taken as a clean-cut phrase that is projected from the focus morpheme which serves as the head. The details of this are presented in the next section. In focus constructions, only kó and kì seem to work out fine.
a. Adé
$\begin{array}{lll}\text { ni } & \text { ó } & \text { wọlé } \\ \text { FOC } & \text { 3SG } & \text { enter }\end{array}$
'It is Adé that entered (not another person).'
b. Adé kọ́ ni ó wọlé
Adé NEG FOC 3SG enter
'It is not Adé that entered.'
$\begin{array}{lllllll}\text { c. } & \text { Kì } & \text { se } & \text { Adé } & \text { ni } & \text { ó } & \text { wọlé } \\ & \text { NEG } & \text { COP } & \text { Adé } & \text { FOC } & \text { 3SG } & \text { enter }\end{array}$
'It is not Adé that entered.' 
The SN marker kó can be taken as the unmarked negative marker for focus construction based on the following reason: it yields a perfect negative interpretation for a sentence in focus with no additional morpheme as shown in (36b). Kìl, on the other hand, is marked, since it has to combine with the copula se. This is similar to the discussion in the previous subsection where we see that the use of kì and kò requires the presence of a subjunctive marker, bá, which explicitly indicates the modality of the structure with which they are merged. The generalization then seems to be that when an SN marker occurs in a marked position, it may require the presence of an additional morpheme if it does not lead to form-interpretation mismatch.

3.7 Discussion. From the above data, it looks like we can make some generalizations about the SN markers in Yoruba. We can establish that SN markers in Yoruba are generally of the 'strong preverbal type' (Zeijlstra, 2007:502). All of them are to the left side of the VP, with one exception: má appears to have a marked distribution in (32), a phenomenon which I claim arises as a result of modal ambiguity. We have seen that tense does not have anything to do with the choice of the SN markers and that rather their selection is largely determined by aspect, mood, and focus. We have also seen that $k \grave{o}, k o ́$, and kì are unmarkedly used in realis context, while má is unmarrkedly used in irrealis context. The data generally favors the claim in Section 2 that the $k$-morpheme is unmarrkedly realis while the má morpheme is unmarrkedly irrealis. From all the description in Sections 3.1-3.6, we have seen that their usage in different modal or aspectual environments gives rise to two kinds of effects: (a) form-interpretation mismatches (as can be seen in (34) and (35)) and (b) the requirement for an additional morpheme (as we see in (26c), (29), (33), and (36b)).

The description in the above sub-sections presents us with two kinds of what Francis and Michaelis (2003) classify as complexity mismatch where there is no one-to-one correspondence among the elements in the syntactic representation and the elements in the semantic representation of an expression, given the assumption of one-to-one correspondence among levels of representation in the Montague tradition (Partee, 1975:203). For the purpose of explicitness, I refer to these two kinds of complexity mismatch as syntactic complexity mismatch and semantic complexity mismatch. Syntactic complexity mismatch occurs when an element present in the syntax is absent in the semantics, while semantic complexity mismatch occurs when an element present in the semantics is absent in the syntax.

The form-interpretation mismatch identified in (34) and (35) is thus a good example of syntactic complexity mismatch, and our explanation for this is that this arises because an SN marker appears in an environment where it is not unmarkedly used. The syntactic complexity mismatch in (27) and (28) where the 3SG subject is deleted in the presence of kò and kì, however, arises for an independent reason that is different from the fact that kò and kì are used in a marked environment and this may well have an analysis in the widely studied pro-drop phenomenon.

In (22b), (26b), and (33), however, where the SN markers are defaultly used, we see instances of semantic complexity mismatch in that an aspectual or modal interpretation that is present in the semantics is absent in the syntax. We do not yet have an explanation for this kind of mismatch. To account for this, I suggest that this mismatch arises as a result of a generalization that I describe as Default Marking Projection (37).

Default Marking Projection:

If in a workspace, a syntactic object $\mathrm{X}$ projecting a phrase $\mathrm{XP}$ occurs in a functional environment Ey but there is no $\mathrm{Y}$ such that $\mathrm{Y}$ projects $\mathrm{YP}$ then the projection of YP is encoded in X. 
The generalization in (37) is motivated by the following fact: kì can be diachronically broken into $k i$ ' $N E G$ ' and $i$, a progressive marker (Adebayo, 2020). This means that characterizing imperfectivity is already encoded in the SN marker kì so that combining kì with the synchronic progressive morpheme $\dot{n}$ in (22) becomes redundant. Since kò does not have this type of "characterizing" imperfectivity encoded in it, it has to combine with the synchronic progressive morpheme $n$ in (26c). This same explanation is applicable in the case of (33). Since kì and kò are not encoded with subjunctivity (irrealis-ness), they require the presence of a subjunctive (irrealis) marker, bá, to be able to function in this irrealis environment. Má, on the other hand, is encoded with irrealis-ness and so does not require the presence of any irrealis marker. It is the same thing that we see in (22) where the progressive marker $n$ disappears in the presence of the SN marker $k \grave{o}$ such that there is the sense of progressivity in the semantics which has now disappeared in the syntax. We explain this in a similar way: the SN marker kò is encoded with a sense of progressive imperfectivity in (22) so that the use of the progressive marker $n$ becomes redundant when it is used. This means that the instances of semantic complexity mismatches described above are simply instances of cases where two functional interpretations are encoded within a single syntactic object.

A reviewer points out that it is unlikely that, for example, kò in (22) is encoded with a sense of progressive imperfectivity since it appears in perfective environments as well. But the generalization in (37) is a kind of a Paninian generalization which means that the default interpretation of progressive imperfectivity holds only to the extent that there is no syntactic object signaling the environment in which kò occurs. Take for example the expression Ade kò tî̀ kàwé (Ade NEG PRF read.book, 'Ade has not read a book'). The presence of the imperfective marker tî̀ renders (37) inactive in this example since the condition for Default Marking Projection is not met. Further independent illustrations might also be useful in explaining (37). Consider the following argument.

Default marking in natural language is often taken for granted. For example, we know that a sentence like They are nice is a positive statement while a sentence like They are not nice is a negative one. While we often care to point to the presence of NEG (not) to justify why we consider the latter sentence negative, we are often silent about how we come to know that the former sentence is a positive statement. In fact, there is a huge amount of literature on how we know that a sentence is negative than there is on how we know that a sentence is positive. This is so because sentences like the former are the default. However, if we take the principle of Compositionality (one-to-one correspondence between form and interpretation) any seriously, positive statements represent a form of semantic complexity mismatch: the sense of positivity that is present in the semantics is absent in the syntax.

So how do we know that a statement is positive? This question can be approached in two ways: (a) we know because NEG is absent; (b) we know because something is present underlyingly (a covert marker) that tells us that it is positive. If we take (b) which is the most commonly taken route in the syntactic literature to be the more appropriate solution, then our semantic representation of the former sentence must contain a marker that does not have a phonological content. We can call this POS (positive). As such, the interpretation of the former sentence will be something like [They are POS nice] while the latter statement will have something like [they are NEG nice]. The next question to address is how POS gets to the workspace. The Default Marking Projection in (37) gives us a plausible answer: every tense maker in English (and arguably in any language) is defaultly encoded with positivity (POS). The default positive interpretation disappears if NEG is present. This, like the case of $k \grave{o}$, is a Paninian generalization: a general rule (Default Marking Projection) is blocked so that a more specific rule (NEG and PRF independent projections) can be satisfied. 


\section{The syntax of Yoruba SN markers}

In this section, I turn to the syntactic positions of each of the Yoruba SN markers basically from the viewpoint of X-bar schema (Chomsky 1995 and Ouhalla 1999). My purpose is to explore their points of convergence and highlight their differences. I show that, though all of them appear to the left of the VP with some minor variations (and the exception of $m a ́$ ) and can be taken as syntactic heads (Fabunmi 2013), there seem to be some differences in what they c-command as a result of aspect, mood and focus. Following Ouhalla (1999), Fabunmi (2013) proposes that NEG in Yoruba heads its own projection and takes a VP in its complement. While this is reflected in the analysis below, it is shown that NEG takes projections other than the VP in its complement.

There is the question of tense in Yoruba that must be clarified before embarking on this enterprise. Yoruba does not mark tense morphologically but since tense category is a salient characteristic of UG and given that tense can be checked by a temporal adverbial in Yoruba, I assume that Yoruba has the category TP which is headed by a null head T and is generated above NegP. This assumption of a null T head is in line with Koopman's Principle of Projection Activation (Koopman, 2000:369). The principle requires that there be movement of some sort, but since this has only a marginal role to play in this paper, the derivation of the movement is assumed. (See Cummings, 2001:277 for a full derivation). In line with this assumption, I suggest that Yoruba has the category TP which can be checked by a temporal adverbial.

In the trees presented subsequently, I abstract away from such functional categories as vP, AgrOP, AgrIOP and CP. These are not reflected in the trees in most cases so that the interaction of NegP with other phrases in the structures can be focused on. Also, to distinguish cases that involve explicit marking of modal elements, I use MoodP (following Boneh and Doron, 2013) to represent the projections that these elements head.

4.1 The syntax of $k \grave{o}$. Generally, $k \grave{o}$ is used in three distinct syntactic environments: where it precedes the VP (38), where it precedes the AspP (39 \& 40), and where it precedes a MoodP headed by the modal lè (41).

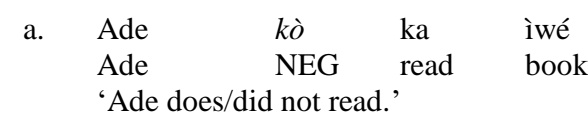

b.

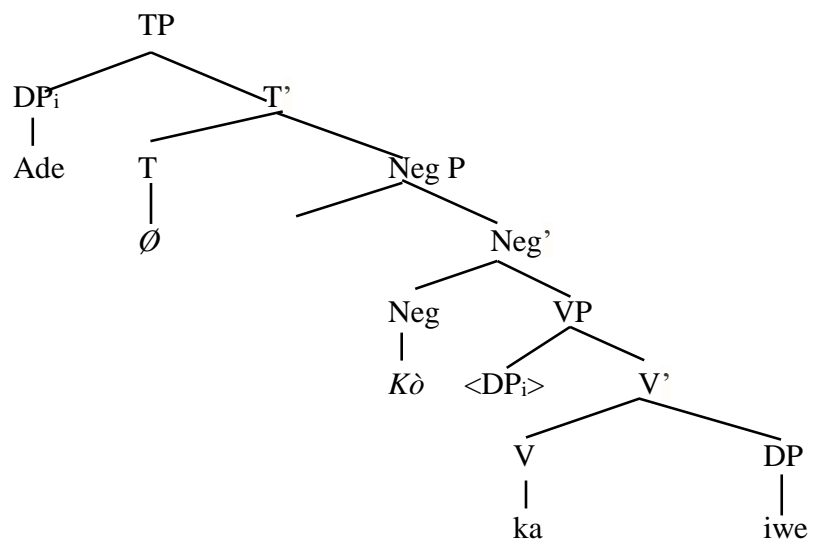


(39)
a. Ade
kò
ń ka
ìwé

'Ade does not read (habitually),

b.

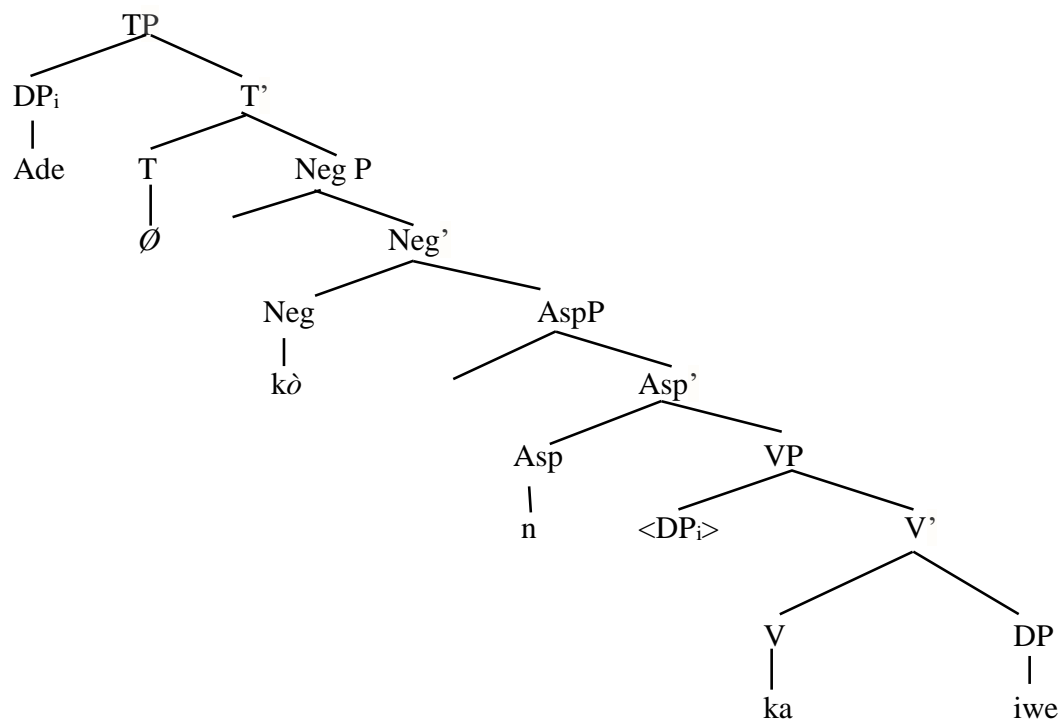

(40)
a. Adé
$k \grave{o}$
tî̀
jẹ ẹ̀wà
Ade
NEG PFV
eat beans
'Ade has not eaten beans.'

b. [TP [Adé [T $\varnothing[\mathrm{NegP}[\mathrm{Neg}$ ' $[\mathrm{kò} \quad$ AspP[tîn $\quad$ vP[jệ $\quad$ DP[ẹ̀wà]]]]]]]]

(41)
a. Ade
kò le
kọ
orin
Adé NEG
'Adé cannot sing.'

b.

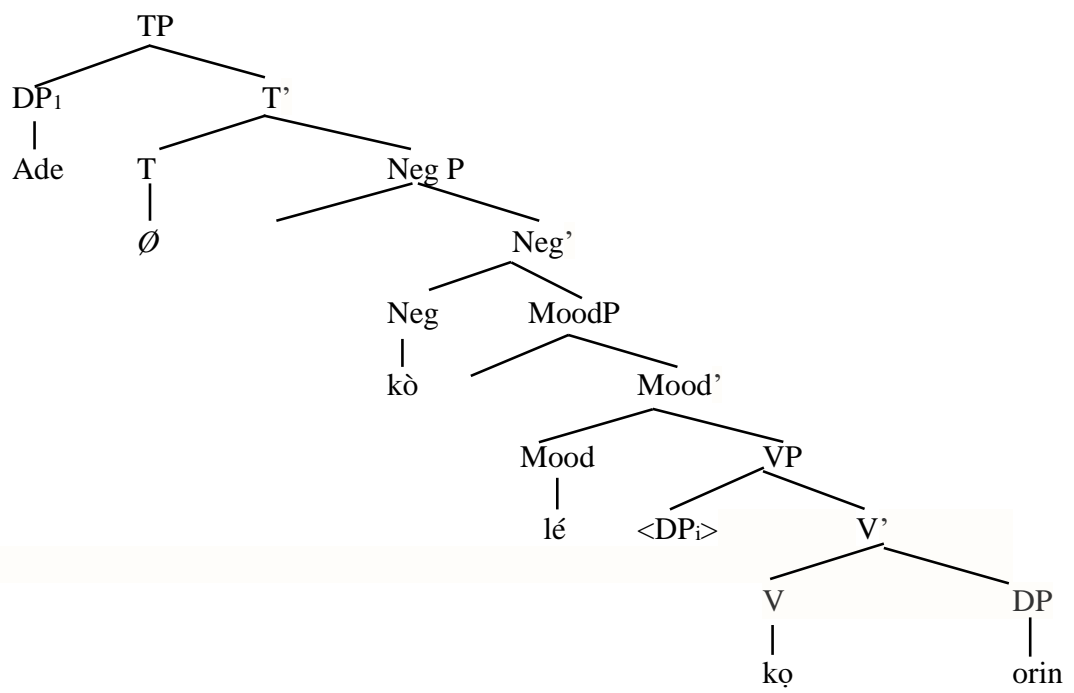


From the schemata above, we have seen that three basic syntactic derivations can be highlighted for $k \grave{o}$ : one in which it selects the VP in its complement (38b), one in which it selects the AspP in its complement (39b and 40b) and one in which a MoodP occupies its complement position (41b).

4.2 The syntax of má. Both uses of má in pure imperatives and modal constructions have the same syntax. Consider (42) and (43).
a. Má
wọ yàrá
yen
NEG
enter
room
that

'Don't enter that room.'
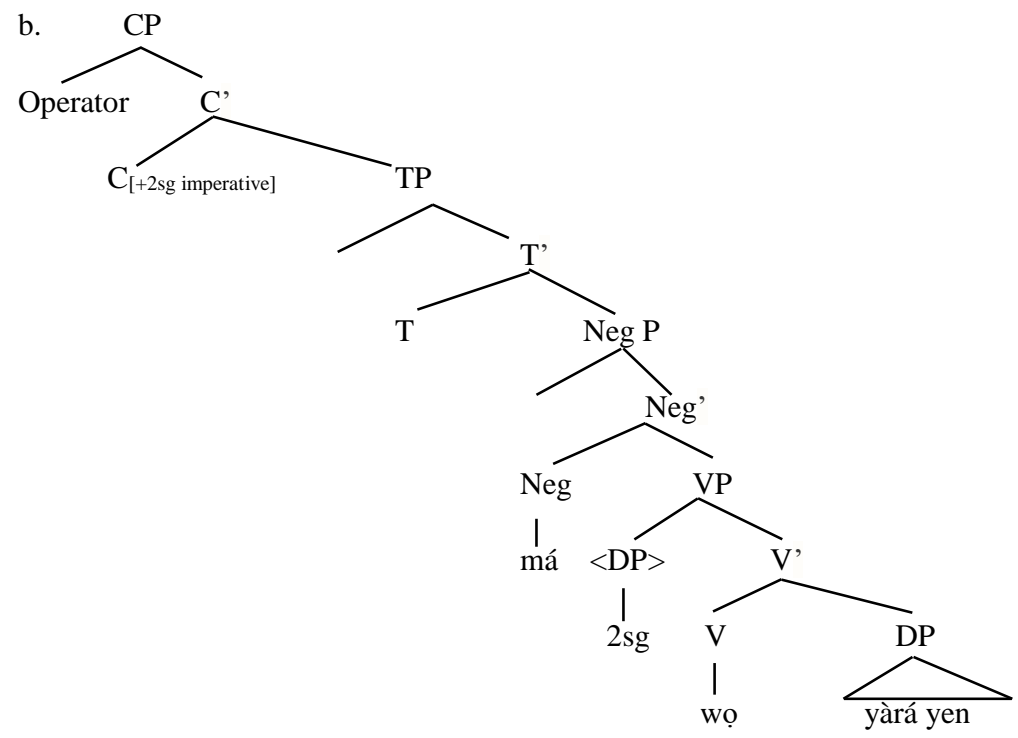

(43)

$\begin{array}{llllll}\text { a. Adé } & \text { lè } & \text { má } & \text { wọ } & \text { yàrá } & \text { yen } \\ \text { Ade } & \text { may } & \text { NEG } & \text { enter } & \text { room } & \text { that }\end{array}$

'Ade may not enter that room.'

b.

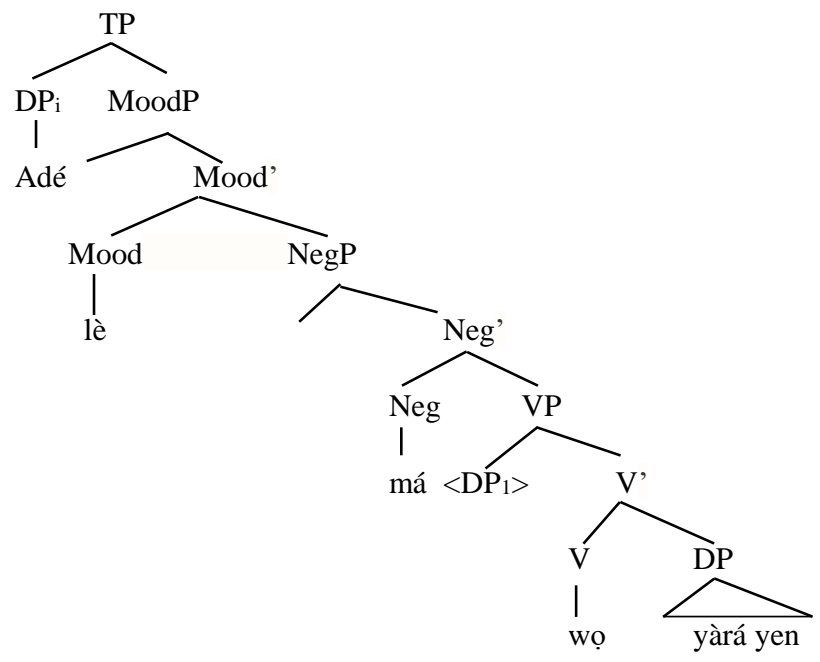


The derivation in (42b) for NEG in the imperative follows the convention in Nchare (2012:397) after Zanuttini (2008). VP is the complement and both are dominated by an Inflectional (or Mood) Phrase.

4.3 The syntax of $\boldsymbol{k} \boldsymbol{o}$. Adewọle (1990) and Fabunmi (2013) take kó as the negator of the NP. This seems to suggest that $k o ́$ has the kind of status that the English 'no' has and to assume that it can form a constituent with an NP to generate a quantifier phrase like 'no planet', 'no teacher', etc. It appears that this may not be the right way to think about the syntax of $k o ́$ for two good reasons. First, this treatment of $k o ́$ does not acknowledge the specific syntactic environment in which $k o ́$ is found, which is focus construction. Second, in a structure like oba kó (king NEG/ 'it is not the king'), $k o ́$ does not negate $o b a$, such that we have something like 'no king' or 'not king', but a whole proposition in which $\rho b a$ is an argument. This proposition must be picked out in context, given the fact that a structure like $o b a k o ́$ is not felicitous out of the blue. So, if one utters $o b a k o ́$ out of the blue, people will be curious to know what proposition is such that it does not apply to oba.

The fact that $k o ́$ cannot be found in any other context than in focus constructions rightly suggests that its syntax must be closely tied to focus. My starting point, therefore, is to propose that Yoruba has a focus phrase that is projected right from the focus morpheme which is its head (44), and then I will argue that it is this (and only this) focus phrase that kó selects in its complement position.

Yoruba has a functional category headed by the focus morpheme $n i$, which projects a Focus Phrase (FocP)

Assuming (44) certainly gives rise to a number of issues that need to be addressed. First, one has to consider the traditional treatment of $n i$, and then assess the legitimacy of the projection that $n i$ heads. Previous works such as Jones (2006) and Bisang and Sonaiya (2000) take $n i$ as a focus morpheme as well as a copula. Generally, $n i$ can be regarded as a copula focus morpheme. In Yoruba, three distinct copula morphemes can be identified: the pure copula jẹ, the emphasis copula se, and the focus copula ni. These three morphemes are described in Hewson (2010), but for a detailed description of $n i$, see Jones (2006) and Déchaine (2002). My assumption in this paper is that $n i$ is primarily a focus morpheme whose copula status is simply secondary and a requirement of its focus status. Assuming that the primary function of $n i$ is to signal focus and that its use in this capacity is in most contexts it occurs, I propose that $n i$ is a functional head, Foc, projecting a whole phrase FocP. This is schematized below.

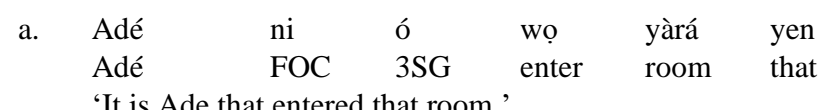

'It is Ade that entered that room.' 
b.

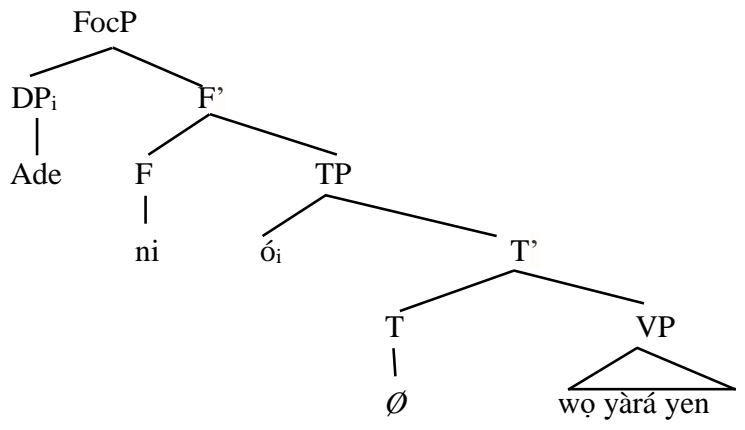

This idea that Yoruba has a distinct focus phrase is conceived in Jones (2006). It can also be found in Awobuluyi (1978) who recognizes that the function of $n i$ is similar to that of the complementizer $t i$ ('which/who') ${ }^{8}$. However, the idea pursued here is different from that of Awobuluyi in the respect that the whole phrase that $n i$ heads is not taken to be a noun phrase but a focus phrase. Assuming that this assumption works out well, I then propose that it is this focus phrase that $k o ́$ selects in its complement as shown in (46b).

a. Ade

Adé

'It is not Ade that entered that room.'

\section{wọ yàrá yen enter room that}

b.

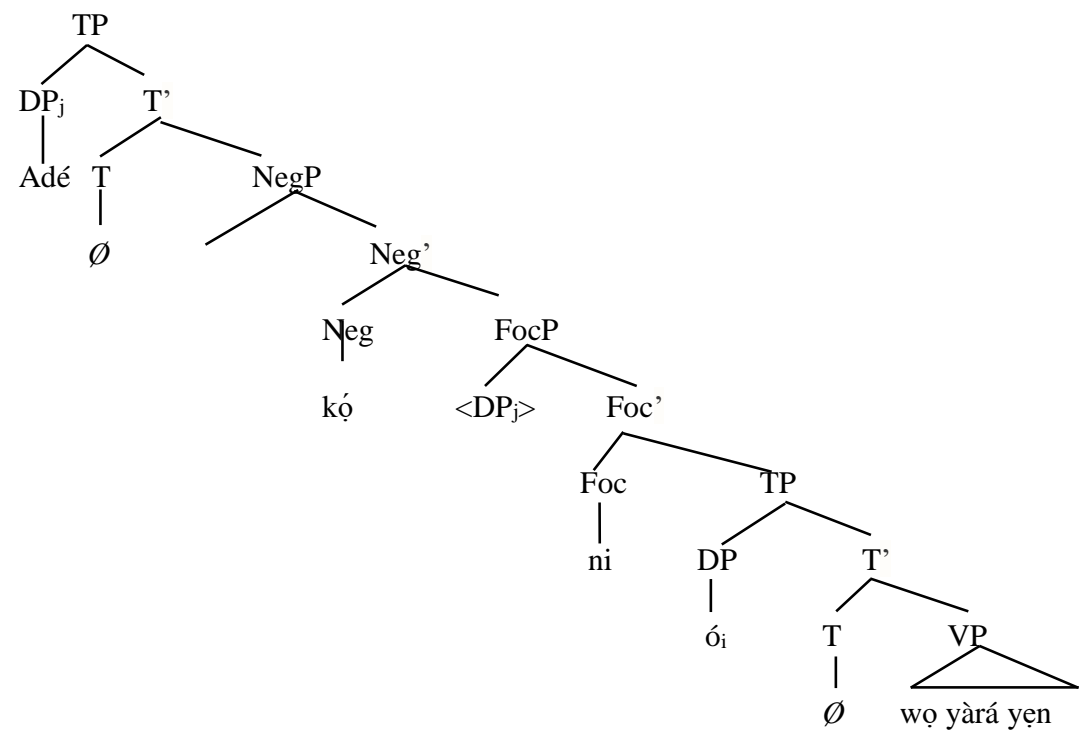

If the foregoing intuition is correct, then we can assume (47). The generalization in (47) is closer to the position taken in Bamgbose (1966) where kó is taken to be a verbal group negator.

Kọ́ negates a focus phrase (FocP) and not an NP.

\footnotetext{
${ }^{8}$ It is worth noting, however, that there are some works (such as Owolabi, 1983, 1987 and Yusuf 1990) which hold contrary views on this.
} 
One of the fundamental characteristics of the FocP headed by $n i$ is that it takes a TP complement. In (46b), $\mathrm{DP}_{1}$ which originates from within the VP moves to the Spec of the lower TP to check case, but it raises away to land at the Spec of FocP to be picked out from alternatives and finally to the Spec of the higher TP to check case. The $o$ in the Spec of the lower TP is inserted to satisfy EPP (following Adesola (2010)). It should be noted that the multiple case checking of $\mathrm{DP}_{1}$ in the lower clause and then in the matrix clause is predicted to be impossible by the generalized activity condition (Chomsky 2008:150) which posits that Case valuation can only take place once. However, studies such as Bejar and Massam (1999) have shown that this prediction is not compatible with the empirical data from languages like Niuean, Latin, Hungarian, Norwagian and Icelandic. Because in all the data that they examine the highest Case valuation is always the one pronounced, they offer a Case-checking Case-assignment proposal where a DP leaves its Case subscript behind in a lower Case-checking position when it moves to check another Case higher in the structure. I assume this analysis in (46b) as a heuristic to get us going.

4.4 The syntax of kìi. Kî́ has a similar syntax with kò when it is used to negate a habitual sentence as in (48). The only difference is that the aspectual head is not phonologically available in the syntax, unlike what obtains for $k \grave{o}$ in $(39 \mathrm{~b})$ where $n$ is the aspectual head.

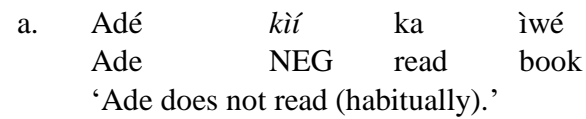

b.

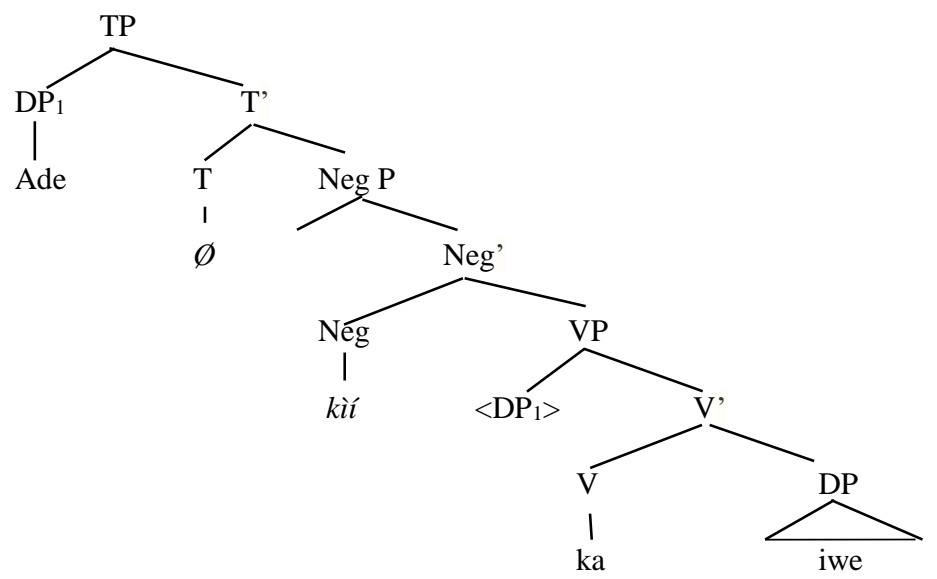

However, its syntax seems to be markedly different when it negates a focus sentence like (49a) as it is extra-clausal in this case, unlike as in (48b). To negate a focus construction, kì has to combine first with the emphasis copula se, and then with FocP. This is illustrated in (49b).

\begin{tabular}{|c|c|c|c|c|c|c|}
\hline $\begin{array}{l}\text { Kìı } \\
\text { NEG }\end{array}$ & $\begin{array}{l}\text { se } \\
\text { COP }\end{array}$ & $\begin{array}{l}\text { Adé } \\
\text { Ade }\end{array}$ & $\begin{array}{l}\mathrm{ni} \\
\text { FOC }\end{array}$ & $\begin{array}{l}\text { ó } \\
3 \mathrm{SG}\end{array}$ & $\begin{array}{l}\text { wọ } \\
\text { enter }\end{array}$ & $\begin{array}{l}\text { yàra } \\
\text { room }\end{array}$ \\
\hline
\end{tabular}


b.

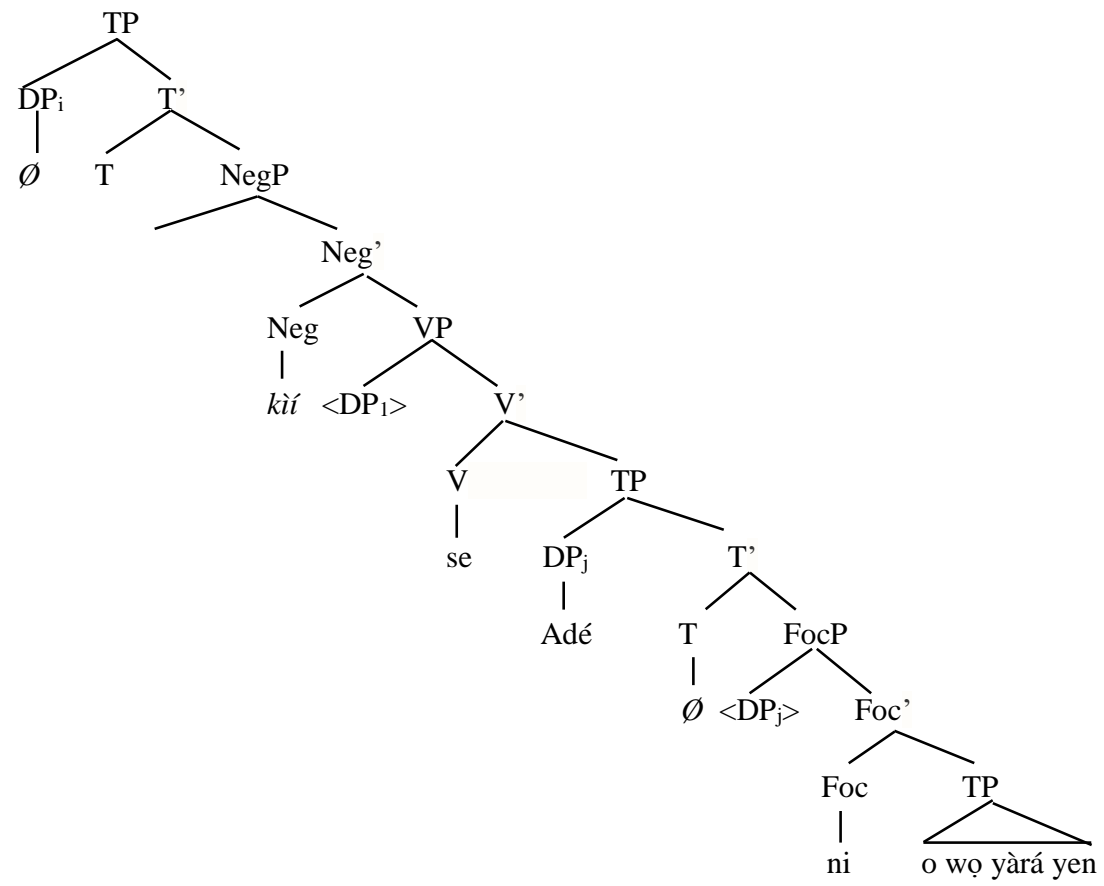

Note that $\mathrm{DP}_{\mathrm{i}}$ represents the $3 \mathrm{SG}$ that is deleted by kit. This is described in section 3. This syntax of kil makes it distinct from the others as this is the only instance where negation appears to be extraclausal. That is, NEG is not syntactically embedded in the clause that it negates. Kì can be paraphrased as 'it is not the case that...', while everything that the higher VP dominates can be paraphrased as 'It is Ade that entered that room'. Combining both, we have something like 'It is not the case that it is Ade that entered that room'. The syntax of kil here appears to mirror its wide scope semantic interpretation; no other SN marker in Yoruba has this syntactic representation.

4.5 Summary. Among all the four Yoruba SN markers analyzed, only kó has a unified syntax, having FocP in its complement position, suggesting that it is not sensitive to aspect. The rest have at least two syntactic analyses, having variations in what they select in their complement positions and the scope they take in syntactic representation. My argument is that these variations are parametric on aspect and mood and that tense which is headed by a null head has no significance in the variation.

\section{Conclusion}

I have tried to show that Yoruba has only two morphemes for the expression of sentential negation whose basic difference is modal: the realis $k \mathrm{~V}_{\mathrm{ROOT}}$ morpheme which has kĭ́, kò, and $k o ́$ as allomorphs and the irrealis má-morpheme. It was observed that the use of these morphemes in a different modal-aspectual environment often gives rise to form-interpretation mismatches (Carlson 2006), and the requirement for additional morphemes that may not be required for a default SN marker in a given modal or aspectual environment. While doing this, I suggest alternative ways of looking at negation in the language. For instance, I claim that, rather than being an NP negator, $k o ́$ negates a focus phrase. I also claim that, despite the fact that they are majorly preverbal, the SN markers do not have a unified syntax, at least to the extent that there is no uniformity in their 
syntactic scope and in what occupy their complement positions, and that this variation is only as a result of their interaction with focus, aspect, and mood.

\section{Abbreviations}

$\begin{array}{llll}1 & \text { first person } & \text { FOC } & \text { focus } \\ 2 & \text { second person } & \text { FUT } & \text { future } \\ 3 & \text { third person } & \text { IPFV } & \text { imperfective } \\ \text { ASsNEG } & \text { assimilation NEG } & \text { NEG } & \text { negative } \\ \text { AUX } & \text { auxiliary } & \text { NEG } & \text { negative } \\ \text { CNEG } & \text { copy NEG } & \text { PFV } & \text { perfective } \\ \text { COP } & \text { copula } & \text { PL } & \text { plural } \\ \text { PROG } & \text { progressive } & \text { SN } & \text { sentential negative }\end{array}$

\section{References}

Adebayo, Taofeeq. 2020. Some diachronic changes in Yoruba grammar. Journal of West African Languages, 47 (1), 11-25.

Adesola, Oluseye. 2010. The non-agreeing subject resumptive pronoun in Yoruba. In Aboh, Enoch and James Essegbey (eds.), Topics in Kwa syntax. London: Springer, 65-89.

Adéwole, Lawrence O. 1990. Some Aspects of Negation in Yorùbá. AAP (Koln), 28, 75-100.

Adéwole, Lawrence O. 1999. Negation in Ifẹ̀: A Yorùbá dialect. Journal of Asian and African Studies 58, 397-403.

A Dictionary of the Yoruba Language. 2008. Ibadan: University Press PLC.

Awobuluyi, Oladele. 1978. Essentials of Yorùbá Grammar. Ibadan: Oxford University Press.

Awobuluyi, Oladele. 2016. Ėkó İsèdá-Òrọ Yorùbá. Ibadan: Kingdom Arts Publishing.

Bámgbóșé, Ayo. 1966. A grammar of Yoruba. West African Language Monograph Series No 5. Cambridge: University Press.

Bámgbóșé, Ayo. 1967. A Short Yorùbá Grammar. Ìbàdàn: Heinemann Educational Books.

Bámgbóșé, Ayo. 1990. Fonólójì àti Gírámà Yorùbá. İbàdàn: University Press Limited.

Banjọ, L. A. 1974. Sentence negation in Yorùbá. Studies in African Linguistics, Supplement 5: 3547.

Beja, Susana \& Diane Massam. 1999. Multiple case checking. Syntax 2:2, 65-79.

Bisang, Walter \& Remi Sonaiya. 2000. Information structuring in Yoruba. Linguistics 38, (1):169197.

Boneh, Nora. and Edit Doron. 2013. Hab and gen in the expression of habituality. In Mari, Alda Claire Beyssade, and Fabio del Prete (eds.), Genericity, 176 -191. Oxford: Oxford University Press.

Carlson, N. Gregory. 2006. 'Mismatches' of form and interpretation. In V. van Geenhoven (ed.), Semantics in acquisition, 19-36. Berlin: de Gruyter.

Chomsky, Noam. 1995. The minimalist program. Cambridge: MIT Press.

Chomsky, Noam. 2004. Beyond explanatory adequacy. In A. Belletti (ed.), Structures and beyond: The cartography of syntactic structures, 104-131. Oxford: Oxford University Press.

Chomsky, Noam. 2008. On phases. In R. Freidin, C. P. Otero, and M. L. Zubizarreta (eds.), Foundational issues in linguistic theory: Essays in honor of Jean-Roger Vergnaud, 133-66. Cambridge, MA: MIT Press. 
Collins, Chris \& Paul M. Postal. 2014. Classical NEG Raising. Cambridge, MA: The MIT Press.

Collins, Chris, Paul M. Postal, \& Elvis Yeduvey. 2017. Negative polarity items in Ewe. Journal of Linguistics: 1-35.

Déchaine, Rose-Marie. 2002. Decomposing focus: evidence from Yorùbá. Triggers for Movement Workshop, Tilburg University, October 24-26.

De Haan, Ferdinand. 1997. The interaction of modality and negation: A typological study. London\& New York: Routledge.

Deon, Ashwini. 2009. Unifying the imperfective and the progressive: partitions as quantificational domains. Linguist and Philos 32: 475-521.

Fabunmi, Felix Abidemi. 2013. Negation in sixteen Yorùbá dialects. Open Journal of Modern Linguistics 3 (1): 1-8. http://www.scirp.org/journal/ojml.

Francis, Elain \& Laura Michaelis. 2003. Mismatch: A Crucible for Linguistic Theory. In Francis, Elain \& Laura Michaelis. (eds.), Mismatch: form-function incongruity and the architecture of grammar, 1-30. Stanford Ca: CSLI Publications.

Giannakidou, Anastasia. 2011. Positive polarity items and negative polarity items: variation, licensing, and compositionality. In Maienborn, C., K. von Heusinger, \& Portner, P. (eds.), Semantics: An International Handbook of Natural Language Meaning, 1660-1712. Berlin: Mouton de Gruyter.

Hewson, John. 2010. Yoruba. In Derek, N. Rose, S. \& Hewson, J. (eds.), Verbal Categories in Niger Congo Languages. (http://www.mun.ca/linguistics/nico/Ch21.pdf).

Jackendoff, Ray. 1969. An interpretive theory of negation. Foundations of Language, Vol. 5, No. 2, 218-241.

Jones, Susie. 2006. Focus in Yorùbá: a semantic/pragmatic account. ZAS Papers in Linguistics 46: 143-160.

Kayne, Richard. 2016. The Unicity of There and the Definiteness Effect. Ms., New York University. http://ling.auf.net/lingbuzz/002858.

Klima, Edward S. 1964, Negation in English. In J. J. Katz and J. Fodor (eds.), The Structure of Language. Englewood Cliffs, NJ: Prentice Hall, 246-323.

Koch, Karsten. 2005. N-kí-N in Yorùbá and the semantics of any. http://journals.linguisticsociety.org/proceedings/index.php/BLS/article/download/876/658.

Koopman, Hilda. 2000. The Syntax of Specifiers and Heads: Collected Essays of Hilda J Koopman. London \& New York: Routledge.

Nchare, Abdoulaye. 2012. The grammar of Shupamem. PhD dissertation. New York University, New York.

Ogunbowale, P. O. 1970. The essentials of Yorùbá language. London: Hodder \& Stoughton.

Oke, D. O. 1982. On the use of verbal negators in Yorùbá. In A. Afolayan (ed.), Yorùbá language and literature, 247-263. Ile- Ife: University Press.

Ola, Olanike. 1995. Optimality in Benue-Congo prosodic phonology and morphology. Ph.D. dissertation, University of British Columbia.

Ouhalla, Jamal. 1999. Introducing transformational grammar: From principles and parameters to minimalism. London: Arnold.

Owolabi, K. 1983. More on the inadequacy of focus constructions as noun phrases. Linguistic Analysis 12 (4): $453-471$.

Owolabi, K. 1987. Focus constructions as noun phrases: a critique. Yoruba, Journal of the Yoruba Studies Association, New Series (1): 45-62. 
Partee, Barbara. 1975. Montague grammar and transformational grammar. Linguistic Inquiry 6 (2): 203-300.

Pulleyblank, Douglas. 2003. Yoruba vowel patterns: asymmetries through phonological competition. Ms., University of British Columbia.

Pullum, Geoffrey K., and Rodney Huddleston. 2002. Negation. In Rodney Huddleston and Geoffrey K. Pullum (eds.), The Cambridge grammar of the English language, 785-849. Cambridge: Cambridge University Press.

Yusuf, Ore. 1990. Yoruba copula ni. Journal of West African Languages 20: 83-93.

Zanuttini, Raffaella. 2008. Encoding the Addressee in the syntax: Evidence from English imperative subjects. Natural Language and Linguistic Theory, 26 (1): 185-218.

Zeijlstra, Hedde. 2014. On the uninterpretability of interpretable features. In Kosta, P. (ed.), Minimalism and beyond, 109-129. Amsterdam: Benjamins.

Zeijlstra, Hedde. 2007. Negation in Natural language: on the Form and Meaning of Negative Elements. Language and Linguistics Compass 1: 498-518.

Taofeeq Adebayo <tadebayo@tulane.edu>

Tulane University

New Orleans. Louisiana. 